\title{
Akut pankreatitli hastalarda serum endocan düzeyinin klinikle ilişkisi: Serum endocan akut pankreatitte biyomarker olabilir mi?
}

\author{
Relationship between serum endocan levels and clinical follow-up in patients with acute \\ pancreatitis: Can serum endocan be a biomarker for acute pancreatitis?
}

\author{
Emre DÖNMEZ', Mesut SEZIKLI², Seyyid Bilal AÇIKGÖZ , Hayrünnisa SEZIKLI ${ }^{4}$ \\ S.B. Geyve Devlet Hastanesi, 'iç̧ Hastalıkları Bölümü, Geyve, Sakarya \\ Sağlık Bilimleri Üniversitesi, S.B. Derince Eğitim ve Araştırma Hastanesi, ${ }^{2}$ Gastroenteroloji Kliniği, “Biyokimya Bölümü, Derince, Kocaeli \\ S.B. Kargı Devlet Hastanesi, ${ }^{3}$ ‘ç Hastalıkları Bölümü, Kargı, Çorum
}

Giriş ve Amaç: Akut pankreatit seyrinde hastalığın prognozunu tayin etmek için birçok belirteç ve skorlama sistemleri kullanılmaktadır. Bu çalışmada endocan düzeyinin hafif ve şiddetli pankreatit vakalarında C-reaktif protein, Ranson skoru, revize Atlanta skorlaması ve diğer laboratuvar göstergeleri ile ilişkisi karşılaştırılarak prognozu öngörmede öneminin araştırılması planlanmıştır. Gereç ve Yöntem: Çalışmada 50 akut pankreatit hastası prospektif olarak incelendi, başvuru anı, 2. ve 7. günlerde endocan, biyokimyasal parametreler ve C-reaktif protein değerleri ölçüldü. Hastaların şikayet ile başvuru arasındaki zaman, yatış süreleri, skorlama sistemlerine göre pankreatit şiddeti Ranson ve revize Atlanta skoru olarak kaydedildi. Verilerin istatistiksel analizinde SPSS 22.0 paket programı kullanıldı. Bulgular: Hastaların yaş ortalaması 61.36 \pm 16.21 yıl olup olup \%54'ü kadındı. Ranson skoruna göre 20 olgu (\%30) şiddetli pankreatit idi. Endocan değerleri hafif pankreatit grubu ve şiddetli pankreatit grubu ile karşılaştırıldığında başvuru anında, 2. ve 7. günlerde anlamlı sonuç vermemiştir. Revize Atlanta skorlamasına göre sınıflandırılan hasta gruplarının serum endocan ile karşılaştırılmasında istatistiksel açıdan fark görülmedi. Pankreatit şiddeti için 2. gün bakılan C-reaktif protein şiddetli pankreatitte ortalama $95.05 \mathrm{mg} / \mathrm{L}$, hafif pankreatitte ise 77.06 mg/L olarak saptandı. Diğer laboratuvar göstergelerinden alanin aminotransferaz, aspartat aminotransferaz, gama glutamil transferaz, alkalen fosfataz, total bilirübin ve direkt bilirübin hastalığın şiddeti ile korele saptandı. Sonuç: Akut pankreatit prognozu ile endocan arasındaki ilişkiyi daha net ortaya koymak için daha geniş kapsamlı prospektif çalışmalara ihtiyaç vardır.

Anahtar kelimeler: Akut pankreatit, endocan, Ranson skoru, revize Atlanta skoru, C-reaktif protein
Background and Aims: Several markers and scoring systems are used to determine the prognosis of acute pancreatitis. In this study, the role of endocan in predicting prognosis was investigated by comparing the relation between C-reactive protein, the Ranson score, the revised Atlanta classification, and other laboratory indicators in patients with mild and severe pancreatitis. Materials and Methods: Fifty acute pancreatitis patients were studied prospectively. Endocan, biochemical parameters, and C-reactive protein values were measured at the time of admission and on the second and seventh days. The time between complaints and patient admission, the length of stay, and the severity of pancreatitis according to the Ranson score and revised Atlanta classification were recorded. The SPSS 22.0 statistical package was used for data analysis. Results: The mean patient age was $61.36 \pm 16.21$ years, and $54 \%$ of patients were female. According to the Ranson score, 20 cases (30\%) had severe pancreatitis. When endocan levels in the mild and severe pancreatitis groups were compared at the time of application and at the second and seventh days, there were no statistically significant differences. There were no statistically significant differences in serum endocans between groups of patients classified according to the revised Atlanta scoring system. When patients were subdivided according to pancreatitis severity, the mean C-reactive protein levels on the second day were $95.05 \mathrm{mg} / \mathrm{L}$ in patients with severe pancreatitis and $77.06 \mathrm{mg} / \mathrm{L}$ in patients with mild pancreatitis. Other laboratory indices, such as alanine aminotransferase, aspartate aminotransferase, gamma-glutamyl transferase, alkaline phosphatase, total bilirubin, and direct bilirubin, were correlated with disease severity. Conclusion: To clarify the relationship between the prognosis of acute pancreatitis and endocans, more extensive prospective studies are needed.

Key words: Acute pancreatitis, endocan, Ranson score, revised Atlanta classification, C-reactive protein

tablodur. Hastaların \%80'inde gelişen pankreatit tablosu kendini sınırlayan ve ılımlı olan, nadir lokal ve sistemik komplikasyonlar gelişen ve genel destek tedavisiyle düzelebilen akut ödematöz pankreatit tipindedir. Geri kalan

Dönmez E, Sezikli M, Açıkgöz SB, et al. Relationship between serum endocan levels and clinical follow-up in patients with acute pancreatitis: Can serum endocan be a biomarker for acute pancreatitis? The Turkish Journal of Academic Gastroenterology 2019;18:27-32. DOI: 10.17941/agd.543507 Geliş Tarihi: 12.06.2018 • Kabul Tarihi: 19.07.2018
S.B. Geyve Devlet Hastanesi, İç Hastalıkları Bölümü, Geyve, Sakarya Tel: +90 2645175234 E-mail: emredonmez41@hotmail.com 
\%20 hastadaki tablo ise şiddetli, organ yetmezliklerinin görülebildiği, morbidite ve mortalitenin yüksek olduğu, akut nekrotizan pankreatit şeklindedir (1).

Hastaların klinik olarak gözetiminde günümüze kadar bu amaçla çok sayıda skorlama sistemleri geliştirilmiştir. Bunlardan en çok kullanılanları Ranson, APACHE II ve Atlanta sınıflamaları olup klinik, biyokimyasal ve radyolojik değişkenlere dayanmaktadırlar.

AP hastalarının tedavi yönetiminde ve cerrahi kararının alınmasında, bilgisayarlı tomografi (BT) ve skorlama sistemlerinden elde edilen değerler hastalığın şiddetinin belirlenmesinde önemli bilgiler sunmakla birlikte hastalığın yönetiminde sadece bu değerlerle hareket etmektense hastaların klinik durumunu ve vital bulguları ön planda tutmak daha yararlıdır. Bu nedenle klinik durumu da içine alan daha iyi risk tahmini yapılabilecek belirteç ve sınıflama sistemlerine gerek vardır.

Illk olarak insan umbilikal ven endotelyal hücre kültürlerinde tesbit edilen endocan daha sonra dermal mikrovasküler endotel hücreleri, koroner ve pulmoner arterler, yağ dokusu kapillerleri gibi birçok insan endotel hücre kültüründe üretilmiştir. Septik şok, akciğer, böbrek, kolon kanseri varlığında ve inflamasyonun olduğu durumlarda plazma endocan değerleri yükselmektedir. Son zamanlarda yapılan çalışmalarda endocan düzeylerinde inflamatuvar hastalıklarda artış olduğu, bazı hastalıkların aktivasyonuyla korele arttığı gösterilmiştir.

Literatürde AP hastalarında endocan düzeyi ile ilgili veri bulunmamaktadır. Bu çalışmadaki amacımız AP hastalarında klinik ile endocan düzeyleri arasında korelasyon varıı̆ını, klinik gidişat ile endocan takibinin prognostik değer taşıııp taşımadığını ortaya koymaktır.

\section{GEREÇ ve YÖNTEM}

Bu araştırma hastanemiz Gastroenteroloji servisinde AP tanısı konup yatarak tedavi görmüş 50 hasta üzerinde yürütülmüştür. Hasta ve yakınlarına gerekli bilgilendirme yapılmış ve test için rutin kan örneklemeleri dışında 0 . gün (başvuru anında), 2. gün ve 7. gün ilave $3^{\prime}$ er cc kan alınması için rızaları alınıp çalışmanın hastanede kalış sürelerini etkilemeyeceği ifade edilmiştir.

18-80 yaş aralığında olan ve AP tanısı olan hastalar çaış̧mamıza dahil edilmiştir. Çalışmadan dışlanma kriterleri sigara içiyor olmak, malignite tanısı olmak ve bilinen evre 3 ve üzeri kronik böbrek hastalığı varlığı olarak kabul edilmiştir.

Hastaların cinsiyeti, yaşı, hastanede yatış süresi, ek hastalık varlığı, kullanmakta oldukları ilaçları, alışkanlıkları, geçirilmiş pankreatit varlığı, travma öyküsü, şikayet başlaması ile başvuru arasındaki süresi, laboratuvar inceleme sonuçları ve görüntüleme bulguları kaydedilmiştir. Alanin aminotransferaz (ALT), aspartat aminotransferaz (AST), laktat dehidrogenaz (LDH), gama glutamil transferaz (GGT), alkalen fosfataz (ALP), serum lipid profili, total bilirübin düzeyi, direkt bilirübin düzeyi, serum C-reaktif protein (CRP) düzeyi, tam kan sayımı, üre, kreatinin, serum elektrolit düzeyleri ve açlık kan glukozu düzeyleri incelenmiştir.

Çalışma için Kocaeli Üniversitesi Girişimsel Olmayan Klinik Araştırmalar Etik Kurulu Başkanlığı'ndan izin alınmıştır (Görüşme tarihi 05.10.2016, Karar No KÜ GOKAEK 2016/249).

Endocan için alınan kan örnekleri 10 dakika santrifüj edildikten sonra ayrilan serumlar $-80^{\circ} \mathrm{C}$ 'de saklandı. Serum endocan konsantrasyonu manuel endocan kiti ile ELISA yöntemi ile ölçüldü. (Boster Biological Technology, USA). Endocan testinin test içi ve testler arası varyasyon katsaylsı \%10 ile \%12 arasında değişmekteydi. Endocan testinin sensitivitesi $<10 \mathrm{pg} / \mathrm{ml}$ idi.

\section{İstatistiksel Analiz}

İstatistiksel analiz bilgisayarda SPSS ver. 22.0 programı kullanılarak gerçekleştirildi. Normal dağılım gösteren sayısal veriler ortalamatstandart sapma şeklinde gösterilirken normal dağılım göstermeyen veriler medyan (minimum-maksimum) şeklinde gösterildi. Kategorik değişkenler frekans (yüzde) olarak gösterildi. Numerik değişkenlerin dağılım özellikleri Kolmogorov- Smirnov testi ile değerlendirildi. Normal dağılım gösteren değişkenler için grup karşılaştırmaları student $t$ testi ile normal dağılım göstermeyen değişkenler için grup karşılaştırmaları Mann Whitney U testi ile yapıldı. Sayısal değişkenler arasındaki korelasyon analizi Pearson korelasyon analizi testi ile yapıldı. Kategorik değişkenlerin grup karşılaştırmalarında ki-kare testi kullanıldı. $P<0.05$ istatistiksel olarak anlamlı kabul edildi.

\section{BULGULAR}

Çalışmamıza dahil edilen 50 hastanın 23'ü (\%46) erkek, 27 'si (\%54) kadın idi. Hastalarımızın yaşı 24-80 yıl aralığında olup, yaş ortalaması $61.36 \pm 16.21$ yıl olarak saptandı.

Tüm hastalar Ranson kriterleri kullanılarak sınıflandırıldı. Tüm hastaların ortalama Ranson skoru 2.18 \pm 1.3 idi. Hastalar Ranson kriterleri değerlendirilerek hafif seyirli ve ağır seyirli AP olarak 2 gruba ayrıldı. Ranson skoru 3 ve üzerinde olan toplam $20(\% 40)$ hasta ağır seyirli pankreatit, Ranson skoru 3'ün altında olan toplam 30 (\%60) hasta 
hafif seyirli pankreatit olarak kabul edildi. Gruplar arası incelemede hafif pankreatit grubunda ortalama Ranson skoru 1.23 \pm 0.56 iken, ağır pankreatit grubunda bu değer $3.60 \pm 0.59$ idi. Hastaların Ranson skoru ile ölçülen serum endocan düzeyleri Tablo 1'de belirtilmiş olup istatistiksel olarak anlamlı fark olmadığı tespit edildi.

Tablo 1. Ranson skoru ile endocan arasındaki ilişki

\begin{tabular}{|lcc|}
\hline & & Ranson \\
\hline Endocan 0. gün & $r$ & -0.091 \\
& $p$ & 0.531 \\
\hline Endocan 2. gün & $r$ & 0.122 \\
& $p$ & 0.398 \\
\hline Endocan 7. gün & $p$ & -0.007 \\
& $p$ & 0.960 \\
\hline
\end{tabular}

Ağır ve hafif pankreatit gruplarında 0. gün, 2. gün, 7 . günde ölçülen serum endocan düzeyleri pikogram $/ \mathrm{ml}$ cinsinden, 0. gün serum ALT, AST, ALP, GGT düzeyleri $U / L$ cinsinden, 0 . gün total ve direkt bilirübin düzeyleri $\mathrm{mg} / \mathrm{dL}$ cinsinden verilmiş olup ortalama yaş ve yatış süresi median değerleri Tablo 2'de belirtilmiştir. İstatistiksel olarak değerlendirildiğinde iki grup arasında serum endo- can düzeylerinde anlamlı bir fark yoktu. Ağır pankreatitli hastalarda ALT, AST, GGT, ALP, total bilirübin ve direkt bilirübin değerlerinde istatistiksel olarak anlamlı fark saptandı. Hafif pankreatitli vakalarla şiddetli pankreatitli vakalar arasında yaş açısından istatistiksel olarak anlamlı fark saptandı. Hastaların hastanede yatış süreleri ortalama $6.6 \pm 2.6$ gün idi. Hafif pankreatitli vakaların yatış süresi ortalama 5 gün iken, şiddetli pankreatitli vakaların hastanede kalış süresi 8 gündü. Hafif ve şiddetli pankreatitli vakalar arasında hastanede yatış süreci için istatistiksel açıdan anlamlı fark mevcuttu ( $p=0.004)$.

Hastalarımız revize Atlanta skorlamasına göre şiddeti açısından hafif (n: 32) ve orta şiddetli (n: 18) pankreatit olarak sınıflandırıldı. Revize Atlanta skoruna göre ortalama endocan değerleri ve istatistiksel ilişkisi Tablo 3'te verildi. Veriler arasında istatistiksel olarak anlamlı fark saptanmadı.

Hastaların 2. gün bakılan serum endocan düzeyinin başvuru anındaki (0. gün) seviyelerine göre azalma yüzdesi değerlendirildiğinde revize Atlanta skoruna göre hafif şiddetteki hastalarda azalış yüzdesi \%15,7 (-\%40,9 -\%86,1) iken orta şiddetteki hastalarda azalış yüzdesi -\%4, 1 (-\%20,2 -\%85,1) saptandı. Bu fark istatistiksel açıdan anlamlı değildi (p:,402).

\section{Tablo 2. Ranson skoruna göre hafif ve ağır pankreatitli hastaların karşılaştırılması}

\begin{tabular}{|lccc|}
\hline & Hafif Pankreatit & Ağır Pankreatit & p \\
\hline Endocan 0. gün & $194.7 \pm 86.8$ & $200.0 \pm 70.4$ & 0.812 \\
\hline Endocan 2. gün & $152.9 \pm 82.6$ & $185.2 \pm 104.1$ & 0.253 \\
\hline Endocan 7. gün & $162.7 \pm 91.7$ & $177.3 \pm 105.8$ & 0.618 \\
\hline ALT median (min.-maks.) & $48.0(8.0-389.0)$ & $244.0(13.0-1364.0)$ & 0.001 \\
\hline AST median (min.-maks.) & $54.0(16.0-368.0)$ & $317.0(16.0-786.0)$ & $<0.001$ \\
\hline GGT median (min.-maks.) & $100.0(15.0-835.0)$ & $339.0(15.0-849.0)$ & 0.010 \\
\hline ALP median (min.-maks.) & $113.0(35.0-379.0)$ & $139.5(77.0-387.0)$ & 0.068 \\
\hline Tbil median (min.-maks.) & $0.8(0.2-5.6)$ & $1.9(0.6-7.1)$ & 0.006 \\
\hline Dbil median (min.-maks.) & $0.4(0.1-3.8)$ & $1.2(0.2-5.3)$ & 0.003 \\
\hline Yaş median (min.-maks.) & $61.0(26.0-80.0)$ & $71.0(24.0-80.0)$ & 0.037 \\
\hline Yatış süresi median (min.-maks.) & $5.0(2.0-13.0)$ & $8.0(4.0-13.0)$ & 0.004 \\
\hline
\end{tabular}

ALT: Alanin aminotransferaz, AST: Aspartat aminotransferaz, GGT: Gama glutamiltransferaz, ALP: Alkalen fosfataz, Tbil: Total bilirübin, Dbil: Direkt bilirubin.

Tablo 3. Revize Atlanta skoruna göre endocan ortalama seviyeleri

\begin{tabular}{|lccc}
\hline & Hafif Şiddetli & Orta Şiddetli & p \\
\hline Endocan 0. gün & $187,9 \pm 78,7$ & $219,7 \pm 81,4$ & 0.210 \\
\hline Endocan 2. gün & $152.0 \pm 87.9$ & $201,4 \pm 96,7$ & 0.089 \\
\hline Endocan 7. gün & $157.6 \pm 98.9$ & $196,7 \pm 88,4$ & 0.203 \\
\hline
\end{tabular}


Hastaların 7. gün bakılan serum endocan düzeyinin başlangıç seviyelerine göre azalma yüzdesi değerlendirildiğinde revize Atlanta skoruna göre hafif hastalarda azalış yüzdesi \%15,8 (-\%31,1 -\%86,1) iken orta şiddetteki hastalarda azalış yüzdesi -\%8,3 (-\%39,5 - \%82,8) saptandı. Bu fark istatistiksel açıdan anlamlı değildi (p:,088).

AP'nin etiyolojisi incelendiğinde; hastaların 34'ünde (\%68) biliyer nedenler, 4'ünde (\%8) post-endoskopik retrograd kolanjiyopankreatografi (ERCP), 3'ünde (\%6) ilaca bağlı, 1'inde (\%2) kronik alkolizm, 2'sinde (\%4) hastada anatomik bozukluk saptanırken, 5 hasta (\%10) idiyopatik olarak değerlendirildi. Biliyer kökenli pankreatitlilerin Ranson skor ortalamaları 3 iken non-biliyer pankreatitli grubun Ranson skor ortalaması 1 olup aralarında anlamlı fark saptandı (Tablo 4).

İstatistiksel olarak değerlendirdiğimizde hastaların başvuru anındaki (0. gün), 2. gün ve 7. gün CRP ile başvuru anındaki (0. gün), 2. gün ve 7. gün endocan düzeyleri karşılaştırıldığında korelasyon olmadığı görüldü (Tablo 5).

Ağır pankreatitli hastalarda CRP ortalamaları sırayla 0. gün $20.78 \pm 19.7 \mathrm{mg} / \mathrm{L}, 2$. gün $95.05 \pm 59.01 \mathrm{mg} / \mathrm{L}, 7$. gün $49.6 \pm 42.1 \mathrm{mg} / \mathrm{L}$ saptandı. Hafif pankreatitlerde ise CRP ortalamaları sırayla 0. gün $44.9 \pm 46.4 \mathrm{mg} / \mathrm{L}$, 2. gün $77.06 \pm 59.9$ mg/L, 7.gün $38.1 \pm 32.5$ mg/L olarak saptandı (Şekil 1).

\section{TARTIŞMA}

AP'nin erken dönemde risk sınıflamasını yapmak ve şiddetini belirlemek hastalığın morbidite ve mortalitesini azaltmak açısından önemlidir. Hastalığın şiddetini belirlemek için çeşitli laboratuvar belirteçleri ile skorlama sistemleri üzerinde durulmakta ve çalışmalar yürütülmektedir. Fa-

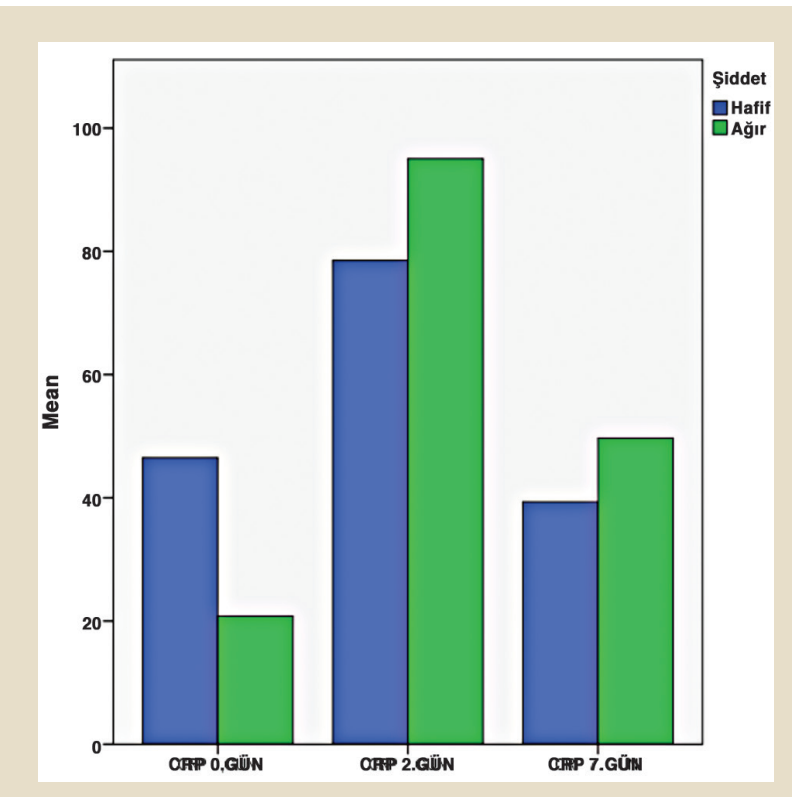

Şekil 1. Hafif ve ağır pankreatitli hastalarda CRP ortalamaları.

kat çalışmaların çoğu zaman hasta sayısının az oluşu, tek merkezli gerçekleşmesi nedeniyle tutarlı sonuçlar elde edilememektedir.

Prognozu öngörmede kullanılan bir çok biyobelirteç arasından klinik takipte sıkça kullanılan CRP düzeyi ölçüm takibi, hematokrit değişimi (0. ve 48. saat), Ranson kriterleri, akut fizyoloji ve kronik sağlık değerlendirmesi (APACHE) II skoru, yatak başı akut pankreatit şiddet indeksi (BISAP) skoru, revize Atlanta Sınıflaması ve Balthazar skorlamasıdır. Bizim bu çalışmamızda Ranson skorlaması, revize Atlanta sınıfladırması, organizmada oluşan sistemik inflamatuvar yanıtı belirlemek için CRP ve serum endocan ölçümleri yapıldı.

Tablo 4. Biliyer ve non-biliyer pankreatitli vakaların ortalama Ranson skorları

$\begin{array}{lccc} & \text { Biliyer } & \text { Non-biliyer } & \text { p } \\ \text { Ranson median (min.-maks.) } & 3.0(0-5.0) & 1.0(0-3.0) & <0.001\end{array}$

Tablo 5. CRP ile endocan arasındaki ilişki

\begin{tabular}{|lcccc|}
\hline & & Endocan 0. Gün & Endocan 2. Gün & Endocan 7. Gün \\
\hline CRP 0. gün & $r$ & 0.201 & -0.369 & -0.263 \\
\hline CRP 2. gün & $p$ & 0.161 & 0.008 & 0.065 \\
\hline CRP 7. gün & $r$ & -0.062 & -0.087 & -0.180 \\
& $p$ & 0.667 & 0.550 & 0.211 \\
\hline
\end{tabular}

CRP: C-reaktif protein 
Ranson kriterleri AP'nin klinik şiddeti ve prognozu hakkında güvenilir bir prediktördür (2). AP'nin etiyolojik ve prognostik faktörlerinin değerlendirildiği derlemede Ranson skoru <3 olan hastalarda ön görülen mortalite oranı yaklaşık \%1, 3-4 olan hastalarda \%15, 5-6 olan hastalarda \%40 ve $6<$ olan hastalarda ön görülen mortalite oranı \%100 olarak belirtilmiştir (3). Atlanta Sempozyumu'nda 1992 'de varılan konsensusa göre Ranson skoru $\geq 3$ şiddetli panreatit olarak tanımlanmaktadır $(4,5)$. AP \%70-80 hafif, \%20-30 şiddetli olarak görülmektedir (6). Bizim de kliniğimizde takip ve tedavi ettiğimiz 50 hastanın 30'u (\%60) hafif, 20'si (\%40) şiddetli AP idi.

Ranson skorlamasına göre hafif ve şiddetli pankreatit olarak 2 gruba sınıflandırılan hastalarımızın endocan ile korelasyonuna bakıldığında istatistiksel olarak anlamlı bir farkılık saptanmadı. Şiddetli pankreatitteki endocan düzeyleri 0. gün (başvuru anı), 2. gün ve 7. günde hafif pankreatite göre yüksek saptansa da vakaların yüksek Ranson skoruna sahip olmamaları, sayıca az olmaları nedeniyle bu oluşan fark istatistiksel olarak anlam oluşturmamış olabilir. Cho ve ark.'Iarının 161 hastayla yaptığı prospektif çalışmada şiddetli pankreatiti ön görmek açısından Ranson $\geq 3$, BISAP $\geq 2$, APACHE-II $\geq 8$, BT şiddet indeksi $\geq 3$ ve 24 . saat CRP $\geq 214 \mathrm{mg} / \mathrm{L}$ olan hastalarda özellikle APACHE-II skorlaması için en yüksek doğruluk saptansa da APACHE-II ve 24. saatte bakılan CRP de dahil olmak üzere tüm skorlama sistemlerinde istatistiksel olarak anlamlı fark saptanmamıştır (7).

Son yıllarda popülerite kazanan, puanlamasında klinik gidişatla birlikte lokal ve sistemik komplikasyonların dikkate alındığı sınıflandırma sistemi olan revize Atlanta skorlamasına göre de hastalarımız kategorize edilip serum endocan ile karşılaştıııldığında anlamlı fark saptanmamıştır; fakat orta şiddetteki olgularda 2. gün ve 7. günlerdeki serum endocan seviyelerinin azalma oranı hafif olgulara göre yüzde değerlerde daha az izlenmiştir ( $p=0.402$, $p=0,88)$. Hasta popülasyonunun daha fazla ve hastalık şiddeti ağır olguların çalışmada yer alması durumunda istatistiksel anlamda değer kazanması muhtemel görünmektedir.

Pankreastaki hasarın derecesi ve organizma yanıtının şiddetine paralel olarak, hepatositlerin sitokinler tarafından uyarılması sonucu, akut faz yanıtı ve bu yanıtın en önemli sonucu olan serum CRP düzeyi artar (8). Akut faz reaktanı olan CRP, hafif ve şiddetli AP atağını ayırmak amacıyla kullanılabilmektedir (9). Serum CRP düzeyi $150 \mathrm{mg} / \mathrm{L}$ üzerinde olmasının, kötü prognozun göstergesi olduğu kabul edilir (10). Semptomlardan sonraki 48. saatteteki CRP değerinin, daha erken ölçülen değerinden daha yararlı olduğu gösterilmiştir (8).
Çalışmamızda ağır pankreatitli hastalarda 48. saat CRP ortalaması $95.05 \pm 59.01 \mathrm{mg} / \mathrm{L}$, hafif pankreatitlerde ise CRP ortalaması 77.06 59.9 mg/L saptandı. Başvuru anı, 2. gün ve 7. gün CRP değerlerinin CRP ile korelasyonuna bakıldığında istatistiksel olarak anlamlı fark görülmedi. Başvuru anındaki CRP değerlerinin şiddetli pankreatite oranla hafif pankreatitli hasta grubunda daha yüksek

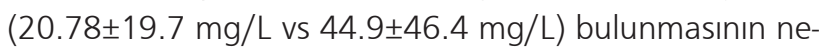
deni AP tablosunun daha erken başlayıp en yüksek görüldüğü 48. saate daha yakın olarak ölçüldüğü olabilir.

Şikayet ile başvuru arasındaki zaman; hafif şiddetteki pankreatit grubunda 14 (2.0-96.0) saat, ağır şiddetteki pankreatitli vakalarda ise 10 (2.0-24.0) saat olarak saptandı. Hafif şiddetteki vakaların başvuru sürelerinin ortalama olarak 4 saat daha geç oldugunu görüyoruz fakat arada oluşan bu fark istatistiksel olarak anlamlı değildi. Doğrusu zaman zaman epigastrik ağrı yaşayan, hastaneye her zaman başvurmayan, tıbbi yardım almadan ayaktan poliklinik takibinde olabilen hastaları da hafif ödematöz pankreatit grubunda düşünecek olursak şiddetli pankreatit ile aralarında istatistiksel anlamda fark oluşabilirdi.

Hastaların hastanede yatış süreleri ortalama $6.6 \pm 2.6$ gün idi. Hafif pankreatitli vakaların yatış süresi ortalama 5 gün iken, şiddetli pankreatitli vakaların hastanede kalış süresi 8 gündü. Hafif ve şiddetli pankreatitli vakalar arasında hastanede yatış süreci için istatistiksel açıdan anlamlı fark mevcuttu (p:0.004). Yatış süresini uzatan sebepler arasında şiddetli pankreatitli vakaların enteral beslenmesinin geç başlayabilmesi, ağrının kontrolü için gereken zamanın daha uzun olabilmesi, sistemik inflamatuar yanıt sendromu (SIRS) belirteçlerinin daha uzun yüksek seyretmesi vardır.

Pankreatit gelişimi sırasında karaciğerde gelişen lipid peroksidasyonu, endotoksin uyarımı sonucu Kuppfer hücrelerinden salınan tümör nekrozis faktör (TNF)-alfa ve pankreatit ilişkili asit sıvısının kaspaz aktivasyonuna neden olması gibi faktörlerin pankreatitte karaciğer fonksiyon testlerinde yükselmeye neden olduğu belirtilmektedir (11). Çalışmamızda ALT, AST, GGT, ALP, total bilirübin ve direkt bilirübin değerlerinin $A P^{\prime}$ de normalden yüksek olmakla birlikte şiddetli grup ile hafif pankreatitli grubu karşılaştırdığımızda istatistiksel olarak yüksek saptanmıştır.

Biliyer kökenli pankreatitlilerin ranson skor ortalamaları 3 iken non biliyer pankreatitli grubun Ranson skor ortalaması 1 olup, aralarında anlamlı fark saptandı ( $p<0.001)$. Zeytunlu ve ark.'ları 177 pankreatitli grupta; interstisyel ödematöz pankreatitili grupta \%74.6 ve şiddetli pankreatit grubunda \%85 oranında biliyer etiyoloji bildirmişlerdir (12). En sık görülen pankreatit nedeninin biliyer olması, 
pankreatit patogenezinde suçlanan mekanizmaların (pankreas kanalıın obstrüksiyonu ve entero-pankreatik reflü) en sık biliyer nedenlerde olması şiddetli pankreatitlerde biliyer sebepleri ön plana çıkarıyor olabilir.

Kronik inflamatuvar hastalıklardan olan Behçet Hastalığı'nda endocan ilişkisini gösteren Balta ve ark.'Iarının yaptığı çalışmada 33 Behçet hastasının plazma endocan düzeyi, 35 sağlıklı gönüllüye göre yüksek saptanmıştır ( $p$ $<0.001$ ). Endocan düzeyi; CRP, eritrosit sedimantasyon hızı ve hastalığın aktivitesi ile ciddi pozitif korelasyon göstermiştir (13).

Scherpereel ve ark., yoğun bakım ünitelerine ciddi sepsis veya septik şokla başvuran hastaların plazma endocan düzeylerini karşılaştırmışlardır. Septik şok hastasının endocan düzeyleri 20 sağlıklı gönüllüye ve 7 SIRS hastasına göre anlamlı olarak yüksek bulunmuştur ( $p<0.001$ ). Araştırmacılar bu bulgulara dayanarak, endocan düzeyi ile hastalığın ciddiyeti ve mortalitesi arasında ilişki olduğunu belirtmiş ve endocanin endotel disfonksiyonunun bir

\section{KAYNAKLAR}

1. Stone HH, Fabian TC, Dunlop WE. Gallstone pancreatitis biliary tract pathology in relation to time of operation. Ann Surg 1981;194:305-12.

2. Balthazar EJ, Ranson JH, Naidich DP, et al. Acute pancreatitis: prognostic value of CT. Radiology 1985;156:767-72.

3. Leung TK, Lee CM, Lin SY, et al. Balthazar computed tomography severity index is superior to Ranson criteria and APACHE II scoring system in predicting acute pancreatitis outcome. World J Gastroenterol 2005;11:6049-52.

4. Bollen TL, van Santvoort HC, Besselink MG, et al; Dutch Acute Pancreatitis Study Group. The Atlanta Classification of 71 acute pancreatitis revisited. Br J Surg 2008;95:6-21.

5. Bradley EL 3rd. A clinically based classification system for acute pancreatitis. Summary of the International Symposium on Acute Pancreatitis, Atlanta, Ga, September 11 through 13, 1992. Arch Surg 1993;128:586-90

6. Taşkın B, Nazlı O, Çökmez A, et al. Akut pankreatit olgularının değerlendirilmesi. Klinik ve Deneysel Cerrahi Dergisi. 1995; 3: 235.

7. Cho JH, Kim TN, Chung HH, Kim KH. Comparison of scoring systems in predicting the severity of acute pancreatitis. World J Gastroenterol 2015;21:2387-94. belirteci olabileceğini ortaya koymuşlardır. Her ne kadar inflamatuvar hastalık komorbiditesi olan hastaları çalışma dışı bırakmış olsak da komorbiditesi olan AP vakalarının daha ağır geçtiği de bilinen bir gerçektir. Bizim çalışmamızda AP olguları ile endocan arasında bir korelasyon bulunmamasının bir sebebi de bu durumdan kaynaklanmış olabilir.

Elde ettiğimiz sonuçlar neticesinde endocan düzeyleri ile AP klinik seyri arasında anlamlı ilişki olmadığını fakat tüm pankreatit vakalarında genel olarak başvuru anında, 48. saatte ve 7. günde yükselme eğiliminde olduğunu, şiddetli $A P^{\prime}$ de daha da yüksek olduğunu tespit ettik. Çaısşmamıza alınan hasta sayısının yetersizliği bu değerlendirmeyi sağlıkı kılacak ve kesin bir cut-off değer verecek düzeyde olmayabilir. Sonuç olarak daha fazla sayıda, daha geniş hasta gruplarıyla yapılan çalışmalarda daha anlamlı sonuçlar elde edilebilir. Sağlıklı gönüllülerden oluşturulan kontrol grubu ile karşılaştırılma yapılsaydı, en azından şiddetli pankreatit geçiren hastalar için anlamlı fark saptanabilirdi.
8. Dambrauskas Z, Gulbinas A, Pundzius J, Barauskas G. Value of routine clinical tests in predicting the development of infected pancreatic necrosis in severe acute pancreatitis. Scand. J Gastroenterol 2007;42:1256-64.

9. Chen CC, Wang SS, Chao Y, et al. C-reaktif protein and lactate dehydrogenase isoenzymes in the assesment of the prognosis of acute pancreatitis J. Gastroenterol Hepatol 1992;7:363-6.

10. Digalakis MK, Katsoulis IE, Biliri K, Themeli-Digalaki K. Serum profiles of CRP, IL-8 and TNFalfa in patients with acute pancreatitis. HPB Surg 2009;2009:878490.

11. Mozzhelin ME, Vengerovskii Al, Sukhodolo IV, Saratikov AS. Liver damages during experimental acute pancreatitis. Bull Exp Biol Med 2001;132:647-9.

12. Zeytunlu M, Akyıldız M, Tekeşin $\mathrm{O}$, et al. Evaluation of acute pancreatitis according to international association of pancreatology guidelines. Akademik Gastroenteroloji Dergisi 2005;4:146-53.

13. Balta I, Balta S, Koryurek OM, et al. Serum endocan levels as a marker of disease activity in patients with Behçet disease. J Am Acad Dermatol 2014;70:291-6. 